International Scientific Journal "Internauka”. Series: "Economic Sciences"

http://www.inter-nauka.com/magazine/economy/

Економіка та управління підприємствами

УДК 338.1:658

Сосновська Ольга Олександрівна кандидат економічних наук,

дочент кафедри фінансів та економіки

Київський університет імені Бориса Грінченка

Сосновская Ольга Александровна

кандидат экономических наук,

дочент кафедры финансов и экономики

Киевский университет имени Бориса Гринченко

Sosnovska Olga

$P h D$ in Economics,

Associate Professor of the Department of Finance and Economics

Borys Ghrinchenko Kyiv University

Кузбіт Свгенія Богданівна

магістр спеціальності «Фінанси, банківська справа та страхування»

Київського університету імені Бориса Грінченка

Кузбит Евгения Богдановна

магистр специальности «Финансы, банковское дело и страхование»

Киевского университета имени Бориса Гринченко

Kuzbit Jevghenija

Master of the Specialty «Finance, Banking and Insurance» of the Borys Ghrinchenko Kyiv University

ТЕОРЕТИЧНІ АСПЕКТИ УПРАВЛІННЯ РИЗИКАМИ ПІДПРИЕМСТВА

ТЕОРЕТИЧЕСКИЕ АСПЕКТЫ УПРАВЛЕНИЯ РИСКАМИ ПРЕДПРИЯТИЯ 


\section{THEORETICAL ASPECTS OF RISK-MANAGEMENT OF THE ENTERPRISE}

Анотація. Сучасний розвиток ринкових відносин супроводжується впливом різноманітних факторів нестабільного економічного середовища, що мають як позитивний, так $i$ негативний вплив на господарську діяльність підприємств. Як результат, підприємства функиіонують в умовах ризикового бізнес-середовища, яке може завдати значних витрат та мати відповідний вплив на рівень їх економічної безпеки.

Сучасний стан економічного розвитку країни, щуо відбувається в умовах науково-технічного прогресу, глобалізащії та економічного відновлення, потребує від українських підприємств проведення аналізу прочесів, які відбуваються на внутрішньому та зовнішньому ринках, для забезпечення ефективного ведення бізнесу.

Отже, в сьогоднішніх умовах для ефективного ведення господарської діяльності та подальшого розвитку, потрібно своєчасно реагувати на зміни та негативні прояви у зовнішньому та внутрішньому середовищах иляхом застосування ефективних методів ризикменеджменту на підприємствах. $У$ зв'язку з ијм, дослідження теоретичних аспектів управління ризиками підприємства є актуальним питанням. Розібравшись із різними способами та підходами ризикменеджменту, y підприсмства з'являсться можливість не просто передбачити зміни, які наближаються, але й підготуватися до них.

У статті проведено дискусійний аналіз поняття «управління ризиками підприємства». Наведено класифікацію основних ризиків та надано характеристику групам ризиків залежно від їх можливих проявів та способу їх контролю. Досліджено сутність та специфіку управління ризиками підприємства. На основі систематизаџї поняття управління ризиками підприємства представлено поетапний процес їх управління, 
International Scientific Journal "Internauka”. Series: "Economic Sciences"

http://www.inter-nauka.com/magazine/economy/

реалізація якого дозволить підприємствам своєчасно ідентифікувати ризики шляхом прийняття раџіональних управлінських рішень для підтримання належного рівня їх економічної безпеки.

Ключові слова: підприємство, управління ризиками, класифікація ризиків, етапи управління ризиками, економічна безпека.

Аннотация. Современное развитие рыночных отночений сопровождается воздействием различных факторов нестабильной экономической среды, имеющих как положительное, так и негативное влияние на хозяйственную деятельность предприятий. Как результат, предприятия функиионируют в условиях рискованной бизнес-среды, которая может нанести значительных затрат и иметь соответствующее влияние на уровень их экономической безопасности.

Современное состояние экономического развития страны, происходит в условиях экономического восстановления, глобализации и научно-технического прогресса, и требует от украинских предприятий проведения анализа процессов, происходящих на внутреннем и внешнем рынках, для обеспечения эффективного ведения бизнеса.

Следовательно, в сегодняшних условиях для эффективного ведения хозяйственной деятельности и дальнейтего развития, нужно своевременно реагировать на изменения и негативные проявления во внешнем и внутреннем средах, путем применения эффективных методов риск-менеджмента на предприятиях. В связи с этим, исследование теоретических аспектов управления рисками предприятия является актуальным вопросом. Разобравшись с различными способами и подходами риск-менеджмента, у предприятия появляется возможность не просто предусмотреть изменения, которые приближаются, но и подготовиться к ним. 
В статье проведен дискуссионный анализ понятия «управление рисками предприятия». Приведена классификация основных рисков и охарактеризованы группь рисков в зависимости от их возможных проявлений и способа их контроля. Исследована сущуность и специифика управления рисками предприятия. На основе систематизацчии понятия управления рисками предприятия представлень поэтапный процеес их управления, реализация которого позволит предприятиям своевременно идентифицировать риски путем принятия рациональных управленческих решений для поддержания надлежащего уровня их экономической безопасности.

Ключевые слова: предприятие, управление рисками, классификация рисков, этапь управления рисками, экономическая безопасность.

Summary. The current development of market relations is accompanied by the influence of various factors of the unstable economic environment, which have both a positive and a negative impact on the economic activity of enterprises. As a result, enterprises operate in a risky business environment, which can lead to significant costs and have a corresponding impact on their level of economic security. Consequently, in today's conditions for effective economic activity and further development, it is necessary to react in a timely manner to changes and negative manifestations in the external and internal environments by applying effective methods of risk management at enterprises. Under these conditions the study of theoretical aspects of enterprise risk management is a topical issue.

The article deals with the discussion of the concept of enterprise risk management. The classification of risks is presented and the characteristics of risk groups with their possible manifestations are given. The essence and specificity of enterprise risk management are investigated. On the basis of systematization of the concept of enterprise risk management, a step-by-step 
process of risk analysis is presented for their further management. This analysis will allow enterprises to quickly identify risks for making sound management decisions to maintain an adequate level of their economic security.

Key words: enterprise, risk management, risk classification, stages of risk management, economic security.

Постановка проблеми. В умовах активізації сучасних глобалізаційних процесів та науково-технічного прогресу спостерігається негативний вплив кризових явищ на розвиток підприємницької діяльності. За останні 10 років кількість та різноплановість світових загроз стрімко зросла. Сучасне бізнес-середовище стало набагато складнішим у порівнянні 3 попередніми роками, в результаті чого, крім нових можливостей, мають місце нові загрози та ризики. У зв'язку з цим виникає гостра потреба в управлінні даними ризиками 3 метою їх мінімізації та нейтралізації. Адже в умовах нестабільної економічної ситуації проблема управління ризиком є досить важливою для будь-якого підприємства та є актуальною у всіх сферах його діяльності. Отже, для досягнення бажаного економічного результату дуже важливо правильно оцінити умови сучасного бізнес-середовища та обрати методи управління, які будуть спрямовані на попередження або зниження ризику.

Аналіз останніх досліджень і публікацій. Проблемам управління ризиками на підприємстві присвячено велику кількість робіт таких вітчизняних та зарубіжних авторів як Гранатуров В.М.[2], Доба Н.M. [4], Лук'янова В.В. [8], Устенко О.Л. [10], Хохлов Н.В. [11], Цвігун Т.В. [12]та інші. У зв’язку з постійними змінами економічної ситуації та порушенням економічної безпеки підприємств необхідність проведення досліджень за даним напрямком потребує нових наукових результатів, адаптованих до сучасних умов та тенденцій економічного розвитку. 
Формулювання цілей статті (постановка завдання). Мета статті полягає у вивченні теоретичних аспектів управління ризиками та етапів його реалізації для забезпечення економічної безпеки підприємств в умовах динамічного економічного середовища.

Виклад основного матеріалу. Підприємництво є однією 3 головних ознак ринкової економіки та основою розвитку народного господарства будь-якої країни. Аналіз сучасних економічних реалій свідчить про наявність тенденції збільшення кількості підприємств в Україні, чверть яких мають негативний фінансовий результат. При цьому найбільший вплив на розвиток підприємств мають такі показники як рівень інфляції (базовий індекс інфляції в Україні у 2018 році складає 105,6), вартість кредитів (у 2018 році: у національній валюті - 23,4 \% річних та в іноземній валюті - 6,2 \%) [3], рівень оподаткування (за міжнародним рейтингом Doing Business Україна у 2018 році посідає 76 місце з 190 країн світу [1]), корумпованість (за світовим Індексом сприйняття корупції Україна у 2017 році посіла 130 місце з 180 країн світу) [5].

Аналіз вищезазначених показників дозволяє констатувати, що економічна ситуація в Україні характеризується певними недоліками, існування яких частково обумовлено наявністю ризикових явищ та процесів. Отже, управління ризиком є необхідним процесом, ефективна реалізація якого дозволить мінімізувати потенційні негативні наслідки шляхом створення системи економічної безпеки підприємства для його стійкого функціонування. У цьому зв'язку, вважаємо доцільним розглянути сутність поняття управління ризиком, що має доволі різні тлумачення у науковій літературі (Таблиця 1). 


\section{Дискусійна трактовка поняття «управління ризиком»}

\begin{tabular}{|c|c|}
\hline Хохлов Н. В. & $\begin{array}{l}\text { Багатоступінчастий процес, ціллю якого є зменшення або } \\
\text { компенсація збитків для об'єкта при настанні несприятливих подій } \\
{[11, \text { с.16]; }}\end{array}$ \\
\hline Лопатовський В. Г. & $\begin{array}{l}\text { Прийняття рішень } \quad \text { в } \\
\text { урахуванням ризиків, що вплесі }\end{array}$ \\
\hline Шпандарук В. О. & $\begin{array}{l}\text { Процес виявлення й оцінювання ризиків, а також вибір методів та } \\
\text { інструментів управління для оптимізації ризику }[13, \text { с.242]; }\end{array}$ \\
\hline Карпунцов М. & $\begin{array}{l}\text { Система цілеспрямованих заходів, які передбачають виявлення, } \\
\text { оцінку ризик-факторів, що негативно впливають на життєдіяльність } \\
\text { підприємства, розробку механізмів протидії їх впливу }[6, \text { с.73]; }\end{array}$ \\
\hline Сліпачук C. & $\begin{array}{l}\text { Це не тільки заходи щодо зменшення негативного ефекту впливу } \\
\text { виникаючих ризиків на досягнення цілей компанії, але й рішення, } \\
\text { прийняті в умовах ризиків, які можуть принести додатковий дохід } \\
\text { компанії в прогнозованому періоді }[9, \mathrm{c} .86] ;\end{array}$ \\
\hline Лук'янова В.В. & $\begin{array}{l}\text { Процес розробки та впровадження програми зменшення будь-яких } \\
\text { випадкових виникаючих збитків (втрат) }[8, \text { с.112]; }\end{array}$ \\
\hline Доба Н. М. & $\begin{array}{l}\text { Інтерактивний процес з чітко визначеними етапами, за допомогою } \\
\text { якого менеджери можуть ясно уявити ризики, з якими стикається їх } \\
\text { організація }[4, \text { c. } 28] \text {; }\end{array}$ \\
\hline Цвігун Т.В & $\begin{array}{l}\text { Спеціальний вид управлінської діяльності, який спрямований на } \\
\text { ефективний захист підприємства від небажаних закономірних чи } \\
\text { випадкових обставин (подій), які в кінцевому результаті можуть } \\
\text { негативно впливати на роботу підприємства }[12, \text { с.28]; }\end{array}$ \\
\hline Устенкои О. Л. & $\begin{array}{l}\text { Процес впливу на суб'єкт господарювання, при якому } \\
\text { забезпечується максимально широкий діапазон охоплення } \\
\text { можливих ризиків, їх обгрунтоване прийняття та зведення ступеня } \\
\text { їх впливу до мінімальних меж, а також розробка стратегії поведінки } \\
\text { даного суб'єкта в разі реалізації конкретних видів ризику [10]; }\end{array}$ \\
\hline Гранатуров В. М. & $\begin{array}{l}\text { Сукупність методів, прийомів, заходів, що дозволяють певною } \\
\text { мірою прогнозувати настання ризикованих подій і вживати заходів } \\
\text { щодо виключення або зниження негативних наслідків їх настання } \\
{[2, \text { с. } 7] \text {. }}\end{array}$ \\
\hline
\end{tabular}

Відповідно до вищезазначеного, можемо припустити, що існує така ж кількість різнопланових підходів до визначення методів, механізмів, інструментів управління ризиками та їх використання в управлінській діяльності підприємства. Отже 3 метою систематизації та подальшого вивчення поняття управління ризиками, пропонуємо їх систематизувати за критерієм залежності від джерела ризику і ступеня його контролю, що представлено у таблиці 2. 
Таблиияя 2

Класифікація ризиків за критерісм залежності від джерела ризику і ступеня його контролю

\begin{tabular}{|c|c|}
\hline Групи ризиків & Фактори \\
\hline \multirow{4}{*}{ Зовнішні ризики (макрорівень) } & Геополітичний \\
\hline & Природний \\
\hline & Демографічний \\
\hline & Ринкова кон'юнктура \\
\hline \multirow{3}{*}{ Зовнішні ризики } & Фінансовий \\
\hline & Соціально-політичний \\
\hline & Конкуренція \\
\hline \multirow{4}{*}{ Внутрішні ризики } & Корпоративний (корпоративна культура) \\
\hline & Управління знаннями \\
\hline & Виробничий \\
\hline & Операційний (управлінський) \\
\hline \multirow{4}{*}{ Змішані ризики } & Власні технології \\
\hline & Комерційні відносини \\
\hline & Інвестиційний \\
\hline & Суспільне сприйняття \\
\hline
\end{tabular}

Джерело: розроблено автором

Отже, за групами можна виділити зовнішні, внутрішні та змішані ризики. Зовнішні ризики - це ризики, що виникають поза організацією та є некерованими з боку підприємства. До зовнішніх ризиків на макрорівні можна віднести наступні фактори:

- геополітичниий - ризик глобального масштабу, що впливає на здатність держави відстоювати свої інтереси на міжнародній арені;

- природний - ризик забруднення навколишнього середовища, що призводить до додаткових витрат підприємства внаслідок зростання ціни на електроенергію, скорочення запасів природних ресурсів та інших негативних ситуації;

- демографічний - це ризик, що виникає внаслідок суттєвих змін демографічної ситуації, такої як старіння нації, міжнародна міграція, екологічні катастрофи тощо; 
- ринкова кон'юнктура - ризик, що передбачає наявність економічних коливань, які можуть призводити підприємства до виробничої кризи, зростання собівартості продукції, неплатоспроможності населення i, як наслідок, стану банкрутства.

До зовнішніх ризиків на мікрорівні відносять:

- фінансовий - доступність фінансування, що передбачає наявність фінансування, його терміни, підтримання збалансованого портфеля інвесторів, волатильність ринку, необхідність в надійних механізмах оцінки інвестиційних проектів;

- соціально - політичний - характеризується наявною законодавчою політикою держави 3 регулювання господарської діяльності, податковою системою, політикою регулювання ринкових відносин;

- конкуренція - змушує підприємства до постійної оцінки ринку, яка передбачає аналіз ринкових тенденцій, виявлення прямих та опосередкованих конкурентів, вміння конкурувати, здатність швидко створювати гнучкі стратегії у відповідь на динаміку ринку.

До наступної групи відносяться внутрішні ризики, що виникають всередині організації та $є$ керованими з боку підприємства, а саме:

- корпоративний ризик, що характеризується нестачею висококваліфікованого персоналу, наукових співробітників, нераціональним використанням трудових ресурсів, низькою вмотивованістю кадрів тощо;

- управління знаннями, що включає збір i обмін внутрішніми i зовнішніми знаннями, виявлення прогалин в необхідних наукових $\mathrm{i}$ комерційних знаннях і способи їх усунення, стан технологічної та інноваційної бази виробництва, створення безпеки капіталу знань; 
- виробничий - пов'язаний 3 особливостями виробництва певного продукту або надання послуги, що виробляється або надається підприємством.

Третя група включає змішані ризики, що виникають внаслідок відображення зовнішніх ризиків на діяльність підприємства, а саме:

- комерційні відносини, що включають недосконалі партнерські відносини, оцінку прихильності партнерів та зміну їх пріоритетів тощо;

- інвестиційний ризик, який може бути викликаний браком інвестиційних коштів внаслідок поганого планування, втрати зацікавленості інвесторів, розбіжності думок і цілей інвесторів та підприємств;

- власні технології - ризик незапатентованої інтелектуальної власності, ризик витоку науково-технічної інформації, ризик неправильної оцінки наукових результатів та інші;

- суспільне сприйняття, що відображається на динаміці попиту покупців на нові технології, ціноутворенні на продукти та послуги, а також швидкості їх використання кінцевими користувачами.

Виходячи 3 того, що на сьогодні існує велика кількість факторів ризику, які можуть впливати на підприємство, необхідність в управлінні ними постійно зростає. Адже для стабільного господарювання необхідною умовою $€$ прогнозування ризику та його своєчасна мінімізація або нейтралізація. $\mathrm{У}$ цьому зв'язку, вважаємо доцільним запропонувати уніфікований процес управління ризиками $\mathrm{i}$ визначити логічну послідовність дій, що допоможе вирішити цю проблему. В представлених етапах можна використовувати традиційні методи для аналізу і оцінки ризиків, такі як статистичний, розрахунково-аналітичний та експертний. 
Адже, вважаємо, що такі методи є універсальними для оцінки будь-якої групи ризиків.

Отже, процес управління ризиками підприємства - це багатоступінчата процедура, яка повинна проводитись постійно і кожен етап циклу є важливим та невід’ємним. Так, до етапів процесу управління ризиками можна віднести :

- перший етап - зовнішній аналіз, що передбачає вивчення та аналіз загального стану економіки та сучасних ринкових тенденцій ;

- другий етап - внутрішній аналіз, що передбачає діагностику внутрішнього середовища, тобто визначення сильних та слабких сторін підприємства;

- третій етап - ідентифікація загроз - де ми визначаємо , які існують загрози на даний момент та які можливо з’являться;

- четвертий етап - опис загроз, на якому ми даємо повну характеристику загроз, які ми визначили на попередньому етапі;

- п’ятий етап - оцінка загроз, ми даємо загальну оцінюємо існуючим ризикам, 3 урахуванням їх впливу на економічну безпеку підприємства;

- шостий етап - визначення методів управління, що передбачає обрання потрібних інструментів та методів для управління існуючими ризиками, відповідно до особливостей підприємства;

- сьомий етап -прийняття рішення - на останньому етапі складається план - алгоритм послідовних дій - 3 урахуванням проведеного аналізу та оцінкою впливу ризиків на економічну безпеку підприємства. 


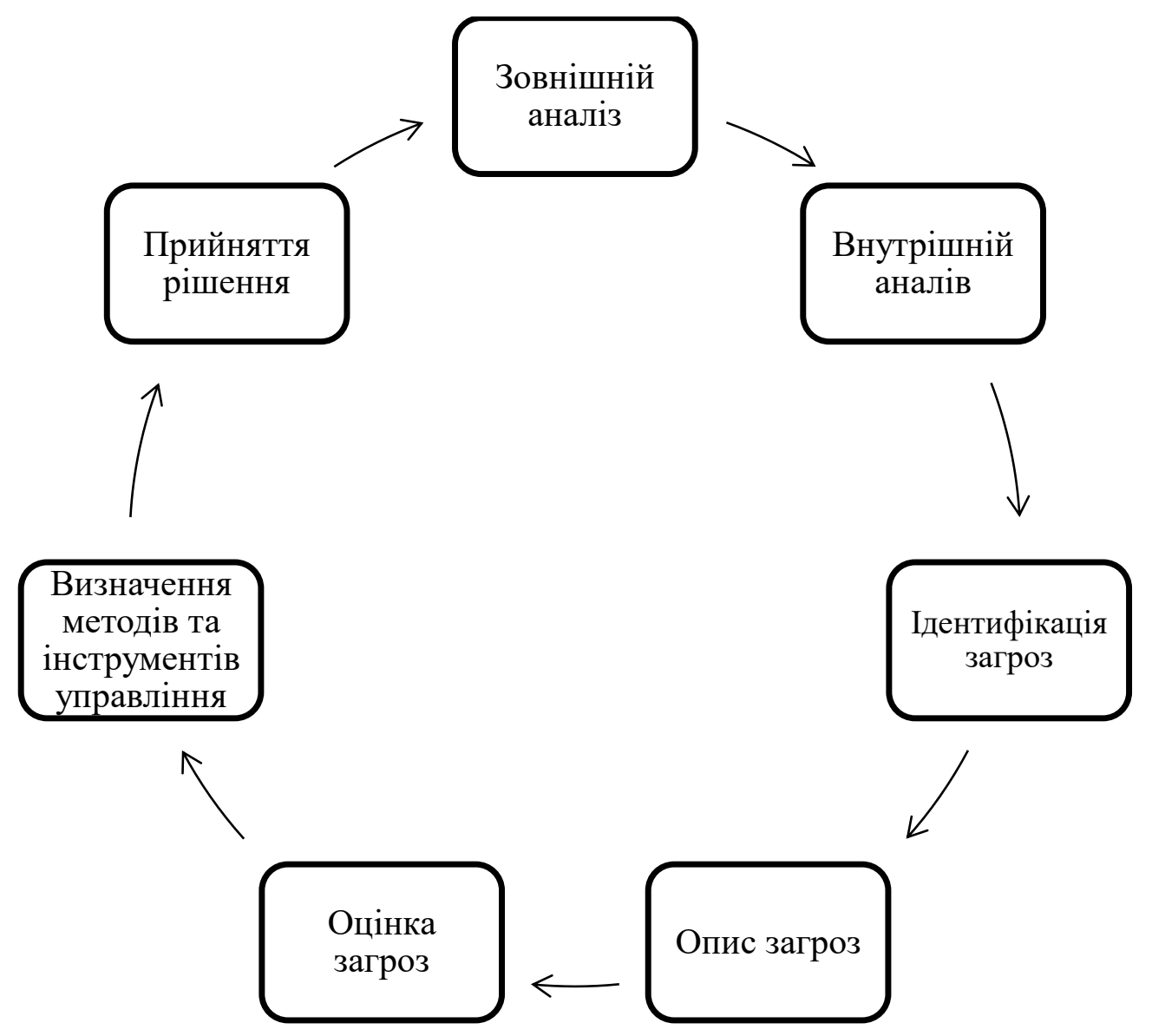

Рис. 1. Етапи процесу управління ризиками

Джерело: розроблено автором

Для цілісної оцінки ризику та прийняття рішення, необхідно мати повну інформацію, отже для початку доцільно проводити зовнішній та внутрішній аналіз економічного середовища. Ці етапи дозволять отримати повну інформацію про існуючі джерела ризиків та провести їх ідентифікацію. Далі відбувається процес оцінки ризиків, що дозволяє визначити їх значимість для підприємства. Важливе значення у процесі управління ризиком належить правильному вибору заходів для зниження та попередження ризику, які загалом визначають його ефективність. Вибір інструментів впливу на різні види господарських ризиків $\epsilon$ досить важливим етапом в процесі управління. На останньому етапі на основі зібраної інформації приймається рішення щодо управління ризиком: 
International Scientific Journal "Internauka”. Series: "Economic Sciences” http://www.inter-nauka.com/magazine/economy/

прийняти конкретний ризик або вжити заходів для мінімізації та нейтралізації.

Висновки і перспективи подальших досліджень. На сучасному етапі українські підприємства тільки виходять 3 економічної кризи та адаптуються до сучасних ринкових відносин. Проте аналіз актуальних економічних реалій свідчить, що діяльність суб’єктів господарювання здійснюється в умовах впливу різноманітних ризиків та загроз. Це вимагає впровадження ефективних методик ризик-менеджменту на підприємстві для підтримання належного рівня його економічної безпеки та забезпечення стійких параметрів розвитку.

\section{Література}

1. DOING BUSINESS-2018. Україна в рейтингу світового банку легкості ведення бізнесу [Електронний ресурс]. - Режим доступу: http://edclub.com.ua/analityka/doing-business-2018-ukrayina-v-reytyngu$\underline{\text { svitovogo-banku-legkosti-vedennya-biznesu }}$

2. Гранатуров В. М. Аналіз підприємницьких ризиків: проблеми визначення, класифікації та кількісні оцінки: монографія / В. М. Гранатуров, І. В. Литовченко, С. К. Харічков; за наук. ред. В. М. Гранатурова. - Одеса: Ін-т проблем ринку та екон.-екол. досліджень НАН України, 2003. - 164 с.

3. Державна служба статистики України [Електронний ресурс] - Режим доступу: http://www.ukrstat.gov.ua/

4. Доба Н.М. Риск-менеджмент: [конспект лекций] / Н. М. Доба; Одес. нац. политехн. ун-т. - О.: Наука и техника, 2009. - 108 с.

5. Індекс сприйняття корупції - 2017 [Електронний ресурс]. - Режим доступу: https://ti-ukraine.org/research/indeks-koruptsiyi-cpi-2017/

6. Карпунцов М. Управління ризикостійкістю підприємства / M. Карпунцов // Економіка та держава. - 2008. - № 9. - С. 72-74. 
7. Лопатовський В. Г. Оцінка необхідності використання процесу управління ризиками на підприємстві / В. Г. Лопатовський // Вісник Хмельницького національного університету. Економічні науки. 2008. - № 6,T.1. - C. 105-108.

8. Лук'янова В.В. Теоретичні аспекти управління підприємством в умовах невизначеності / В. В. Лук'янова // Вісник Хмельницького національного університету. Економічні науки. - 2006. - № 4,Т.1. - С. 111-116.

9. Сліпачук С. Що таке ризик-менеджмент / С. Сліпачук // Контроль. 2009. - № 4. - C. 86-93.

10.Устенко О. Л. Теория экономического риска: монография / О. Л. Устенко. — К. : МАУП, 1997. - 164 с

11.Хохлов Н. В. Управление риском: [учеб. пособие] / Н. В. Хохлов. М.: ЮНИТИ, 1999. - 239 с.

12.Цвігун Т.В., Механізм управління ризиками в системі управління підприємством [Електронний ресурс]. - Режим доступу: http://www.vestnik-econom.mgu.od.ua/journal/2017/23-2-2017/4.pdf

13.Шпандарук В. О. Вдосконалення управління ризиками підприємств на засадах реалізації превентивних заходів / В. О. Шпандарук // Вісник Хмельницького національного університету. Економічні науки. 2010. - №3,T.1. - C. 241-244.

\section{References}

1. DOING BUSINESS-2018. The World Bank. Ease of Doing Business in Ukraine, available as: http://edclub.com.ua/analityka/doing-business-2018ukrayina-v-reytyngu-svitovogo-banku-legkosti-vedennya-biznesu

2. Granaturov V.M. Analysis of entrepreneurial risks: problems of definition, classification and quantitative evaluation: monograph / V. M. Granaturov, I. V. Litovchenko, S. K. Kharichkov; for sciences Ed. VM Granaturov. - 
Odessa: Institute of market problems and ekon.-ekol. Researches of the National Academy of Sciences of Ukraine, 2003. - 164 p.

3. The State Statistics Service of Ukraine, available as: http://www.ukrstat.gov.ua/

4. Doba N.M. Risk Management: [summary of lectures] / N. M. Doba; Odessa nats Polytechnic un - A .: Science and Technology, 2009. - 108 p.

5. Corruption Perceptions Index - 2017, available as: https://tiukraine.org/research/index-koruptsiyi-cpi-2017/

6. Karpuntsov M. Management of risk-taking enterprise / M. Karpuntsov // Economy and the state. - 2008. - No. 9. - P. 72-74.

7. Lopatovsky V.G. Assessment of the necessity of using the process of risk management at the enterprise / VG Lopatovsky // Bulletin of the Khmelnitsky National University. Economic sciences. - 2008. - No. 6, T.1. - P. 105-108.

8. Lukyanova V.V. Theoretical aspects of enterprise management under uncertainty / VV Lukyanova // Bulletin of Khmelnitsky National University. Economic sciences. - 2006. - No. 4, T.1. - P. 111-116.

9. Slipachuk S. What is risk management / S. Slipachuk // Control. - 2009. No. 4. - P. 86-93.

10. Ustenko O. L. The Economic Risk Theory: Monograph / O. L. Ustenko. K.: MAUP, 1997. - $164 \mathrm{p}$

11. Khokhlov N.V. Management of risk: [study. allowance] / N.V. Khokhlov. Moscow: UNITI, 1999. - 239 pp.

12. Tsvigun T.V., Risk Management Mechanism in the Enterprise Management System, available as: http://www.vestnikeconom.mgu.od.ua/journal/2017/23-2-2017/4 .pdf

13. Shpandaruk V.O. Improvement of risk management of enterprises on the basis of implementation of preventive measures / V.O. Spandaruk // 
International Scientific Journal "Internauka”. Series: "Economic Sciences" http://www.inter-nauka.com/magazine/economy/

Bulletin of Khmelnitsky National University. Economic sciences. - 2010. No. 3, T.1. - P. 241-244. 